\title{
浮遊実験における可視化技術*
}

\author{
石川 毅彦**，パラディ ポールフランソワ***
}

\section{Visualization Techniques Used in Levitation Experiments}

Takehiko Ishikawa and Paul-Francois Paradis

\section{1.はじめに}

本稿では，浮遊実験に扔ける可視化技術について紹介 する．宇宙ステーションやスペースシャトルがもたらす 微小重力環境では, 液体を容器を用いることなく保持す ることが可能となる.この無容器状態を用いれば, 容器 からの不純物の混入が避けられ，高純度の材料合成が可 能となる. 更に容器からの核発生が抑制され，深い過冷 却状態（融点以下になっても液体状態であること）が長 時間に亘って得られるため, 通常の方法では測定が不可 能な過冷却融体の熱物性值の測定や，新機能材料の創製 など興味深い研究が可能となる.

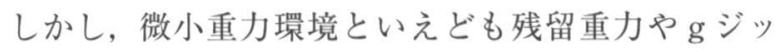
ターなどの擾乱があるため, 工夫なしには浮遊した試料 を科学的な観察に十分なほど精緻に空間に固定すること はできない，そのため, 各国の宇宙機関は様々な方法を 用いた浮遊装置を開発してきた。そしてその技術は現在 地上研究にも転用され，1G下においても様々な試料を 安定して浮遊させることが可能となってきて㧍り, 様々 な観察機構を取り付けて種々の実験が行われはじめてい る.

本稿では, 地上で適用されている幾つかの浮遊法につ いて原理を含めて簡単に紹介するとともに, 浮遊と可視 化技術を組み合わせた実験について, 筆者らが研究開発 を進めている静電浮遊法への適用例を中心として説明す る.

\section{2. 浮遊法}

これまでに考案されている様々な浮遊方式（音波，ガ スジェット, 電磁場, 静電) についてその特徴を簡単に 紹介する.

(1) 音波浮遊法（acoustic method）

音波浮遊法は, 音圧により試料の位置を制御する方法 である.チャンバー内に定在波による安定点(音圧の谷) を作り，この安定点に試料を保持する，この方法では試 料は安定点からずれると, 音圧による復元力が自動的に

* 原稿受付 2005 年 3 月 29 日

** 正会員 宇宙航空研究開発機構 宇宙科学研究本部

*** 宇宙航空研究開発機構 宇宙科学研究本部
働くため, 定在波が維持できれば試料は安定して浮遊す る. 浮遊可能な試料の質量は数 $\mathrm{g}$ であり, あらゆる種 類の試料を浮遊できる. 原理的に定在波を伝える媒体と しての気体が必要であるから, ガス䨌囲気下での実験の みとなる (真空は不可) , 浮遊液滴は音圧により若干変 形する，比較的簡易な制御で実現できるため，装置構成 も簡素である. Fig.1の通り, 試料周りは覆われておら ず，広い観察視野を確保できる。音波浮遊においては雲 囲気ガスによる熱伝導により, 高温の試料から常温の浮 遊チャンバー壁にかけて大きな温度勾配が出来る。音波 浮遊の最大の問題は, この温度勾配中で定在波を維持す ることが非常に困難な点である.このため, 高温の試料 の安定した浮遊に大きな問題がある。この理由から現在 音波浮遊装置は主に低融点試料（常温で液体）の実験に 用いられている.

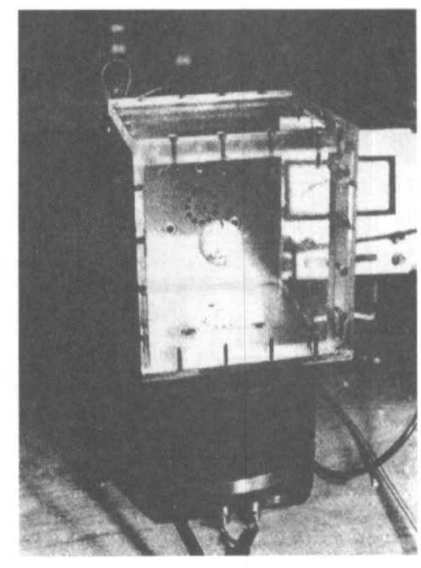

Fig. 1 A ping-pong ball levitated in an acoustic levitator ${ }^{1}$

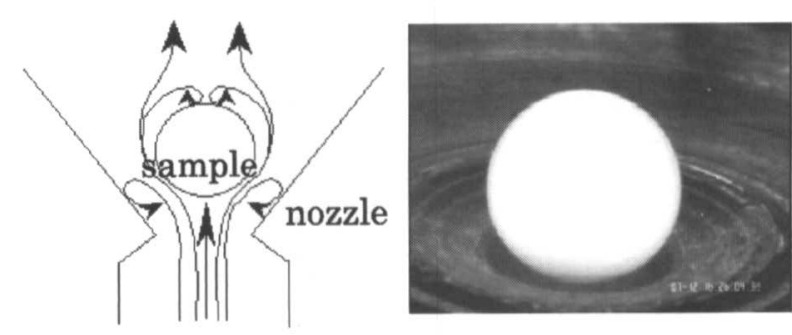

Fig. 2 Schematic drawing of aerodynamic levitation nozzle (left) and a levitated sample (right). 
(2) ガスジェット法 (aerodynamic method)

ガスジェット法は，ノズルの先端から吹き出された高 速の気体が試料の周りを流れる時, 周辺（試料の前方及 び後方）に生じる圧力差による安定点を作って位置制御 を行う方式である(Fig. 2) ${ }^{2)}$. 本方式は簡単な装置で実 現出来, あらゆる種類の試料をガス雲囲気下で浮遊させ ることが出来る. 浮遊可能な試料の大きさは数 $\mathrm{g}$ 程度 であり，浮遊液滴はガス圧によって若干変形する。また， 試料の下部はガ久により冷却されるため, 試料の上下に 大きな温度勾配がつく、試料やガス温度に伴ってガス流 量を制御する必要があるが，音波浮遊より容易であり， 高温においても安定した位置制御が可能である.

(3) 電磁法 (electromagnetic method)

電磁浮遊法は, 高周波磁場により試料に誘導電流を発 生させ，ローレンツカにより試料の位置制御を行う方法 である．試料に誘導電流を発生させる必要があるため浮 遊させることが出来るのは導電性の試料に限られる. 磁 場により大きな力を発生できるので, $\mathrm{kg}$ 単位の大きな 試料を浮遊させることができる(コールドクルーシブル). 高真空及びガス雲囲気に対応可能である.

浮遊のための誘導電流によって試料が加熱されてしま う（浮遊と加熱の独立制御不可）ことや試料内に誘導さ れる流れにより溶融試料の変形が大きいことがデメリッ トとして挙げられる。また, 浮遊用コイル（Fig. 3）の ため, 水平方向からの観察は制約を受ける. 近年, 安田 らにより静磁場装置と電磁浮遊炬とを組み合わせた装置 が開発され，静磁場による流れの抑制効果により試料の 変形が軽減する結果が示されている ${ }^{3)}$. 電磁方式はガス ジェットや音波に比べると複雑であるが, 安定点を維持 すれば高温試料の浮遊溶融が容易に実施できるため, 金 属の浮遊溶融には現在一番多く用いられている.

(4) 静電法 (electrostatic method)

試料を帯電させ, クーロン力により位置制御を行う方 法である. 試料の質量を $m$, 上下の電極間電位を $V$, 電極間の距離を $L$, 試料の電荷量を $Q$, 重力加速度を $g$ とすると, 安定して浮遊する試料には,

$$
m g=Q V / L
$$

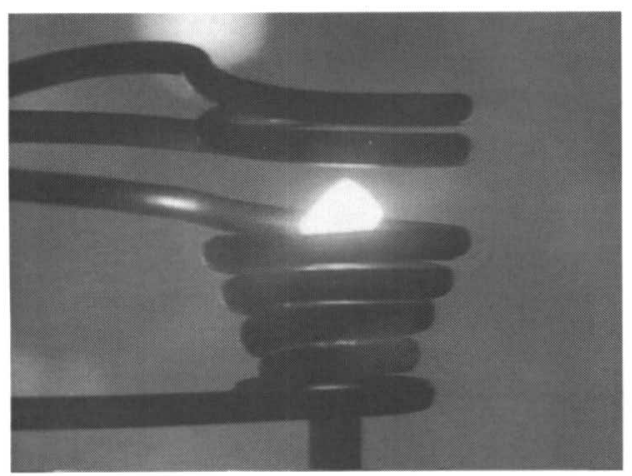

Fig. 3 A sample levitated by an electromagnetic levitator
の関係が成り立つ. 試料の電荷量は, 金属試料で $10^{-10} \mathrm{C}$ 程度である. 電極間距離 $10 \mathrm{~mm}$ で, 質量 $10 \mathrm{mg}$ の試料 の浮遊には $10 \mathrm{kV}$ 程度の高電圧が必要となる。このよ うにクーロン力は小さな力であるため, 地上で浮遊可能 な試料は数百 $\mathrm{mg}$ 程度である. 高真空〜加圧雲囲気に対 応可能であるが, 常圧〜低真空においては電極間の放電 の問題から大きな試料は浮遊出来ない. 電磁浮遊法とは 異なり, 浮遊と加熱は独立しており液滴形状は真球に近 い.また広い観察視野が得られる.

静電方式は, 他の方法と異なり安定点 (ポテンシャル の谷）を作ることができない.つまり, 試料が所定の位 置からずれても復元力は自然には働かない. 従って, 試 料を安定して浮遊させるためには, 試料の位置変化に応 じて電極間の電位を調整するフィードバック制御が必要 となる.この制御ダイアグラムを Fig. 4 に示す(4). 試料 の位置検出はコリメートされたレーザー光により試料の 影をディテクターに投影することにより行う。ディテク ターからの位置情報はコンピュータに入力され, コン ピュータにおいて PID 制御の計算が行われ, 上下の電 極間の電圧が調整される.

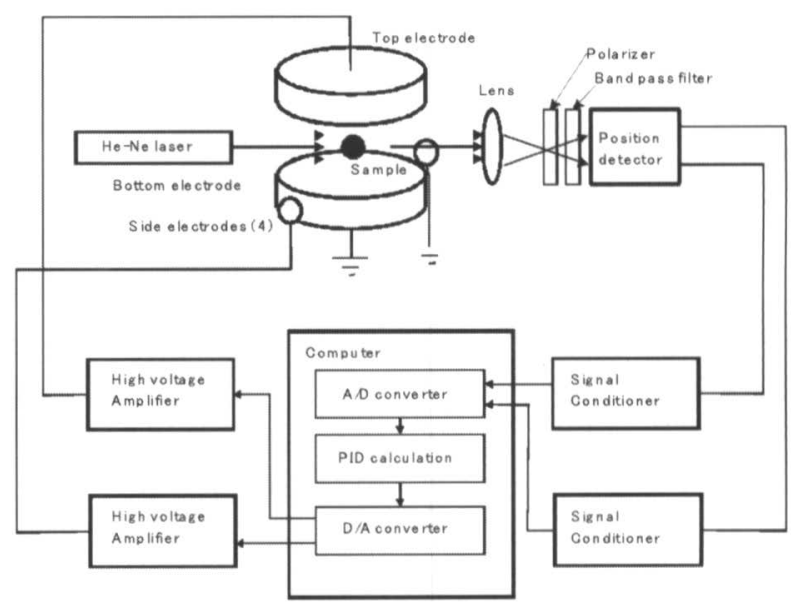

Fig. 4 Block diagram of the position control system in the electrostatic levitator.

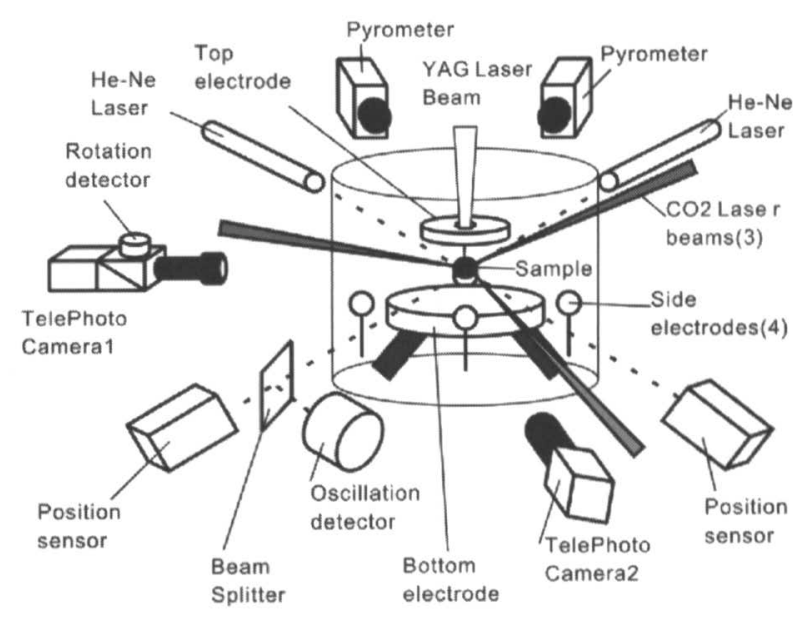

Fig. 5 Schematic diagram of the optical system used in the electrostatic levitator. 
Fig. 5 に筆者らが金属や半導体試料の浮遊溶融に使用 している静電浮遊炉の概要図を示す。この浮遊炬のチャ ンバーは, ターボ分子ポンプにより $10^{-5} \mathrm{~Pa}$ の真空度に 到達する.また, 試料の酸化を抑制するためのサブリメー ションポンプも備えている. 真空チャンバー内には,

Fig. 6 に示す電極が配置されている. $10 \mathrm{~mm}$ 間隔の上下 電極間に高電圧を印加して直径 $2 \mathrm{~mm}$ 程度の試料を浮遊 させる，下電極の周囲には小電極が配置され，小電極電 位の調整によって試料の水平方向の位置制御が行われる。 下電極下部には 4 個のコイルが設置されており,これら のコイルにより回転磁場を作って試料の回転を制御する。 チャンバーは多数の観察空を持ち, 周囲に様々な装置を 配置することが可能である. 試料の位置検出のための $\mathrm{He}$ - Ne レーザー及び位置センサーのセットが 2 組配置 され, 試料の 3 次元的な位置を検出して制御を行う。試 料の加熱は, 2 台の $100 \mathrm{~W}$ 炭酸ガスレーザー及び $500 \mathrm{~W}$ の YAGレーザーを用いて 4 方向から行う.これらの高 出力加熱レーザーにより，金属では最高の融点を持つ夕 ングステン（融点 $3695 \mathrm{~K} ）$ の浮遊溶融が可能である ${ }^{5}$.

Fig. 7 に浮遊する直径 $2 \mathrm{~mm}$ の高融点金属融体の拡大画

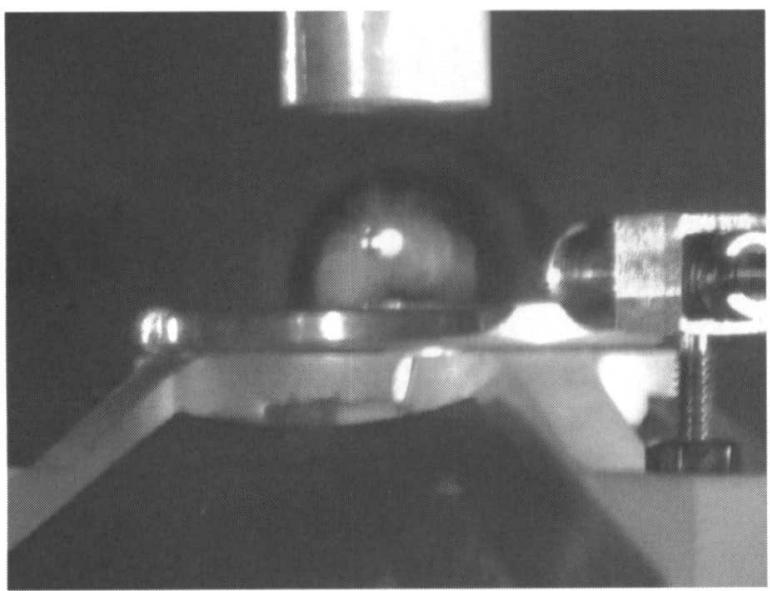

Fig. 6 An levitated sample in the electrostatic levitator in JAXA.

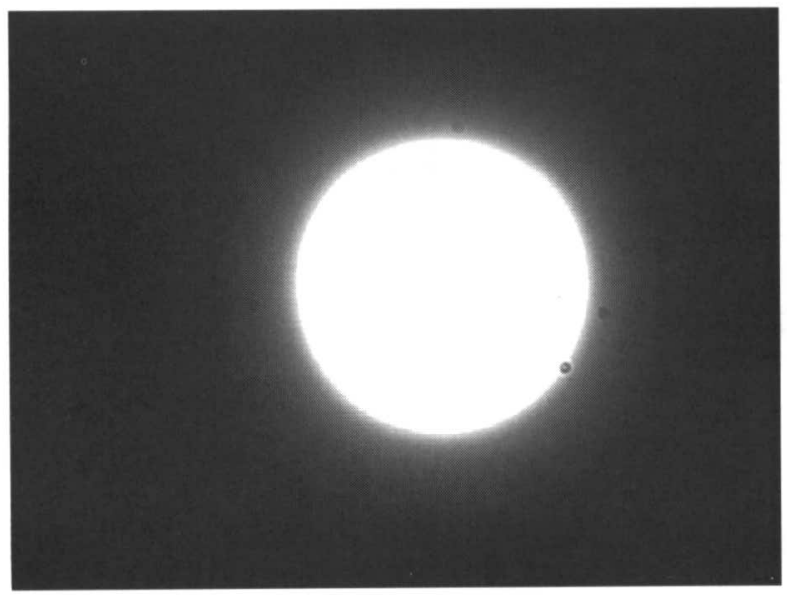

Fig. 7 A molten niobium sample in the electrostatic levitator in JAXA.
像を示す。

\section{3. 浮遊実験における画像処理及び可視化}

一般に高温で浮遊溶融している試料は不透明であり， 内部の可視化は非常に困難である. また, 地上において 高温の試料を安定して浮遊させる技術は近年確立したと ころであり，様々な可視化技術を適用して浮遊試料を観 察する試みは始まったばかりである，本稿では, 高速度 カメラを用いた凝固界面の可視化及び浮遊試料の熱物性 計測における画像処理及び流れの可視化について紹介す る.

\section{1 過冷却凝固における固液界面の可視化}

Fig. 8 に浮遊溶融させた試料を急冷した時の温度一時 間変化（放射温度計で計測）を示す. Fig. 8 の a 点にお いて加熱源（加熱レーザー等）を切ると，試料は輻射に よって熱を失い, 試料の温度は低下していく，容器があ る場合は, 融点において容器壁から核が発生して凝固が 始まり, 凝固が終了するまでの間試料温度は一定（融点 の温度: $T_{m}$ ) となる. しかし, 浮遊融体においては, 容器がないためこの核発生が抑制され, 融点以下でも液 体の状態(「過冷却状態」) となる。 そのまま温度が降下し ていくと, やがて核が発生して凝固が開始（Fig.8のb 点）し, その際に放出される凝固潜熱によって試料の温 度が融点まで上昇する現象 (「復熱現象」)が見られる。こ のように無容器状態では通常の容器を用いた方法とは異 なった凝固過程を経る。このため, 凝固組織も容器を用 いた場合とは異なった組織となり, 特異な性質を持つこ とが期待される．実際, 無容器法によりプロセスした試 料が磁性や耐摩耗性などに優れた性質を示す例が報告さ れている. しかし, 過冷却液体からの凝固過程と生成組 織そして機械的／磁気的性質との関係は体系的に整理は されておらず, 現在, 過冷却状態からの凝固過程を観察 する実験（そして生成した凝固組織との関係を調べる研 究）が進められている ${ }^{6)}$.

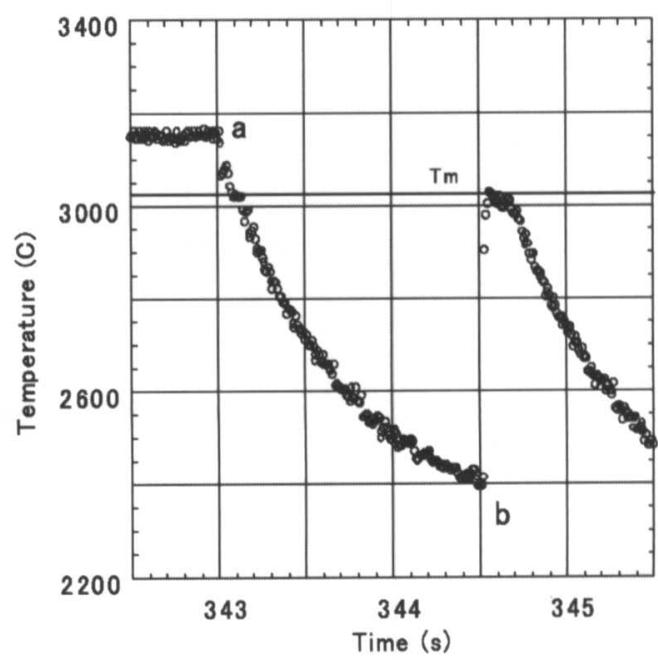

Fig. 8 Typical thermogram of a levitated and radiatively cooled sample 
Fig. 9 に高速度カメラによる凝固界面の観察実験の例 を示す。写真の暗い部分が液体であり，白い部分が固体 である，液体と固体で試料の輻射率が異なることから試 料表面における固液の界面を同定できる。これらの高速 度カメラによる一連の画像から, 試料の凝固速度を求め ることが可能である. しかしながら, 試料は不透明であ るため，試料内部の固液界面の状態を観察することはこ

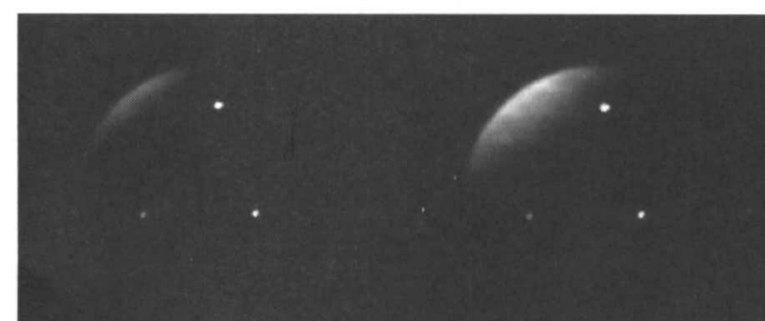

(1)

(2)

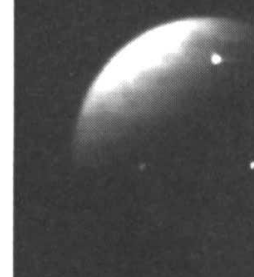

(3)

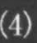

(5)
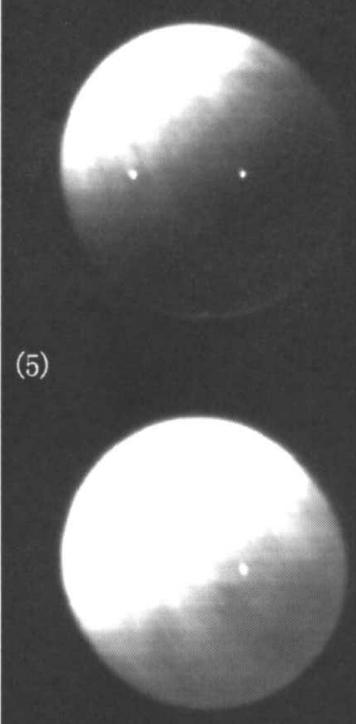

(6)

(7)

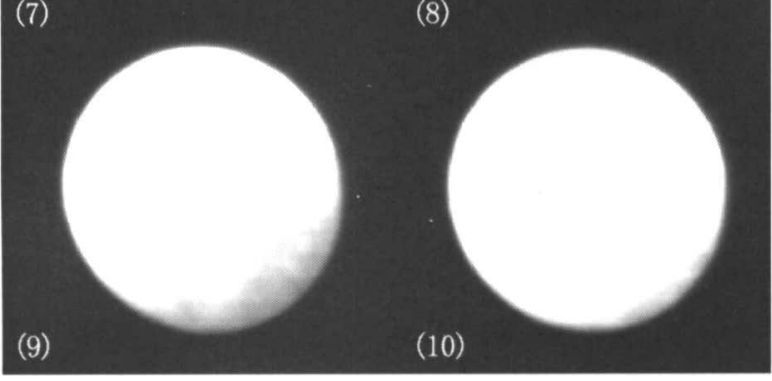

Fig. 9 Images of an electrostatically levitated sample during a solidification process taken by a high speed camera $(1000 \mathrm{~Hz})$.
の方法では不可能である.

\section{2 熱物性測定実験における画像処理及び可視化}

浮遊法を利用した研究の一つとして, 過冷却状態を含 めた幅広い温度範囲での液体の熱物性計測がある。この 計測は液体状態で化学的な活性が高く, 容器との反応が 問題となる高融点金属液体等に非常に有効である.ここ では, 画像処理を利用した密度計測及び表面張力・粘性 係数測定について解説する.

(1) 密度計測

密度は, 質量を体積で割った值であり, 各々を個別に 計測することにより求められる. 質量は, 加熱溶融した 試料の重量を実験後に計量することで得られる. 一方体 積は, 浮遊溶融中の試料の拡大画像から求められる.

Fig. 7 のおおり, 静電浮遊炉において浮遊する液体は表 面の帯電も手伝って, ほほ真球となるため, 画像解析に より容易に体積を求めることが可能である.

画像解析はまず, 画像の輝度変化から試料の輪郭 (エッ ジ）を抽出し, 輪郭を

$$
R(\theta)=\sum_{n=0}^{5} c_{n} P_{n}(\cos \theta)
$$

で表される調和関数にフィッティングする，ここで $P_{n}$ $(\cos \theta)$ は Legendre 多項式である.フィッティングでは 以下の誤差関数 $F$ が最小となるように最小二乗法によ り係数 $c_{0} \sim c_{5}$ を決定する.

$$
F\left(x_{0}, y_{0}, c_{0}, \cdots, c_{5}\right)=\sum_{i=1}^{400}\left[R_{i}-R\left(\theta_{i}\right)\right]^{2}
$$

試料の体積は, 以下の式より $R(\theta)$ から求められる7).

$$
V=\frac{2 \pi}{3} \int_{0}^{\pi} R(\theta)^{3} \sin \theta d \theta
$$

画像解析においては試料のエッジ抽出が精度を決める ため, 試料と背景との良好なコントラスト(輝度の変化) が必要である.

融点が低い試料の密度測定においては背景光として白 色光を用い，背景は白，試料は黒で良好なコントラスト が得られる. しかし, 高融点金属の様な $1500^{\circ} \mathrm{C}$ を越え る高温になると試料からの発光の強度が著しく増加する ため，良好なコントラストが得られなくなる．

Fig. 10 に背景光を変えた場合のジルコニウム $(\mathrm{Zr}$ : 融点 $1850^{\circ} \mathrm{C}$ ) 浮遊試料の画像を示す. (a)〜 (c)は白色背 景光における $\mathrm{Zr}$ 試料の温度と画像の変化を示している。 固体 $\mathrm{Zr}$ （温度約 $1400^{\circ} \mathrm{C}$ ）においては試料が黒色で, 背 景と良好なコントラストが得られている. しかし, 温度 上昇に伴って試料は白色化し, 液体状態では背景との境 界が見えなくなる. (d)〜 f f ) は背景光をなくし, 背景黒, 試料白の画像を得たものである。この場合，良いコント ラストが得られる. しかし, 試料の外周に太陽のコロナ 状のものが観察される. このため, 撮影される試料は実 
際の試料よりコロナの分だけ大きくなることになり，体 積測定上の誤差となる.

これらの問題を解決するため, 背景光に紫外線を用い 紫外線領域の光で観察を行う方法を採用している. 試料 からの光は赤外光が大半であるため, 紫外光の領域のみ で観察を行えば, 試料からの発光の影響は排除できる. 背景紫外光源として紫外線ランプを用い，また拡大カメ ラの前に紫外線パスフィルターを挿入した。こうして撮 影した Zr 試料画像を Fig. 10 の (g) （i)に示す．温度変化 に関わらず，背景と試料間に一定のコントラストが得ら れている.

Fig. 11 に背景光なしの場合と紫外光観察の場合にお ける $\mathrm{Zr}$ の密度測定結果を示す．背景光なしで得られた 融点 $(2128 \mathrm{~K})$ での密度值 $5850 \mathrm{~kg} / \mathrm{m}^{3}$ は，ある文献值 とほほ一致しているため，一概におかしいとは言えない． しかし，その温度係数 $1.83 \mathrm{~kg} / \mathrm{m}^{3} \mathrm{~K}$ は，通常の金属液 体の值より一桁大きく，試料からの発光の影響が無視で

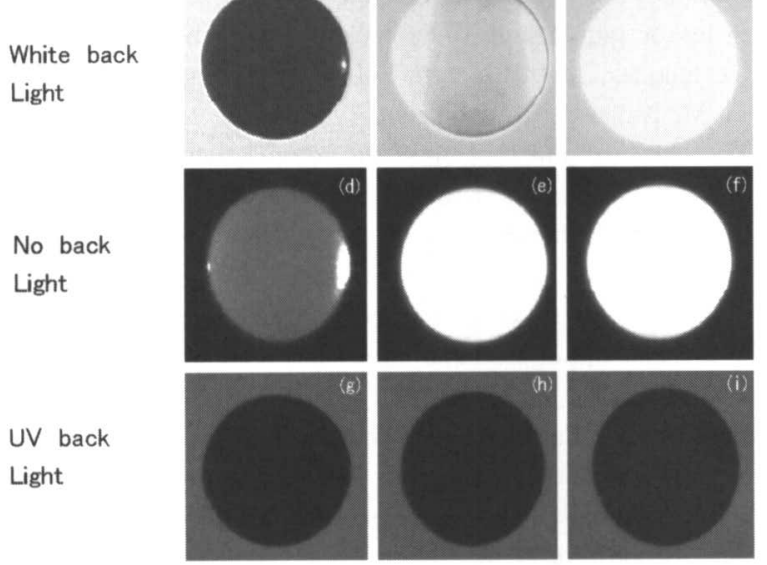

Fig. 10 Images of a levitated sample in different temperatures and with different backgrounds.

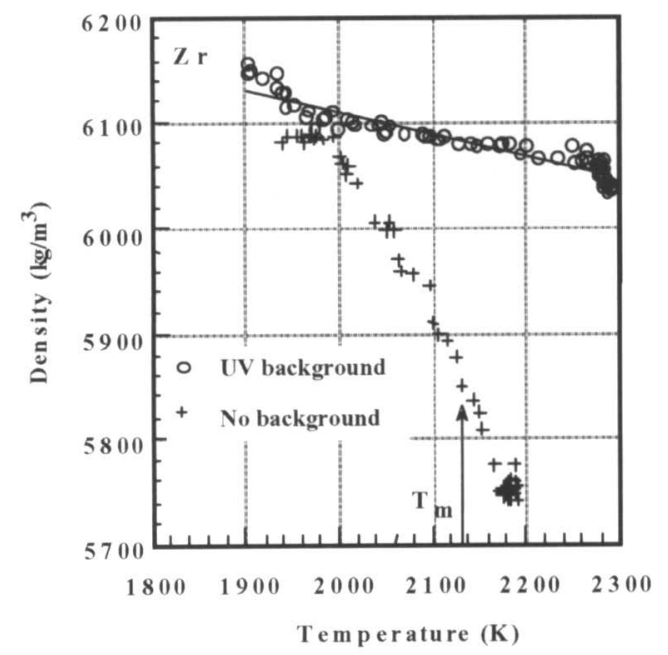

Fig. 11 Effect of background illumination on the density measurements of a liquid $\mathrm{Zr}$ sample.
きないことがわかる，一方，紫外光領域で観察した場合 は, 密度, 温度係数とも妥当な值が得られている ${ }^{8}$.

(2) 液滴振動法による表面張力・粘性係数測定と内部流れ 液滴振動法は，表面張力により球形となった浮遊液滴 に 2 次の振動（Fig. 12）を励起し，穴の固有角速度 $\omega_{2}$ 及び振動の減衰時間 $\tau_{2}$ を計測し (Fig. 13)，以下の基本 式から表面張力 $\gamma$, 粘性係数りを算出する方法である99.

$$
\begin{aligned}
& \omega_{2}^{2}=\frac{8 \gamma}{\rho r_{0}^{3}} \\
& \frac{1}{\tau_{2}}=\frac{5 \eta}{\rho r_{0}^{2}}
\end{aligned}
$$

ここで $\rho$ は密度である．静電浮遊法では，地上におい ても浮遊液滴はほほ真球状になるため, 液滴振動法に よって表面張力及び粘性係数を計測することが可能であ る. Fig. 14 に液滴振動法により計測したニオブの粘性 係数を示す ${ }^{10)}$.このように過冷却を含む広い温度範囲で データの取得が可能である.

ところで，(5)及び(6)式は，

·試料の球からの変形が微小

・外場がない

・試料液体の内部流動はない

という前提の下で導出されたものである. しかしながら, 実際の液滴振動においては振幅は微小とは言えない。 ま た, 浮遊のための電場は存在する上, 内部流動の存在も 否定できない. 特に粘性係数計測は内部の流動に敏感で あるため，正確な粘性係数の導出のためには，液滴振動

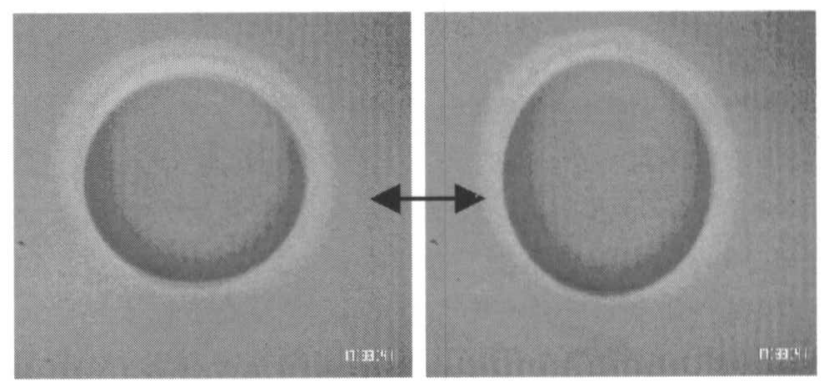

Fig. 12 Typical images of mode-2 oscillation

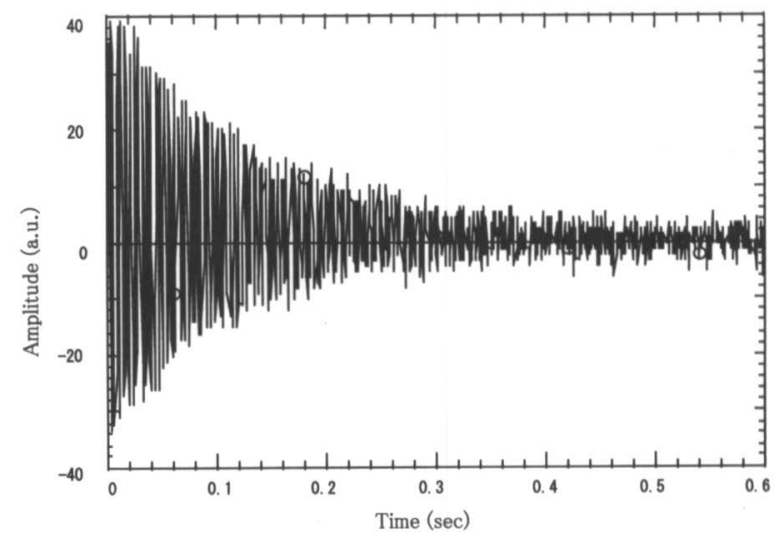

Fig. 13 Typical signal of the decay of oscillation following electrical excitation. 


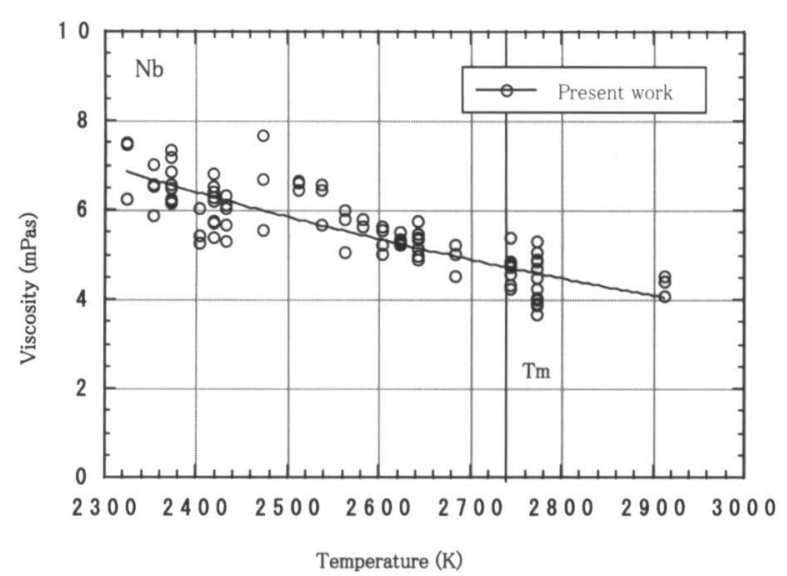

Fig. 14 Measured viscosity of niobium versus temperature. (Tm indicates melting temperature.)

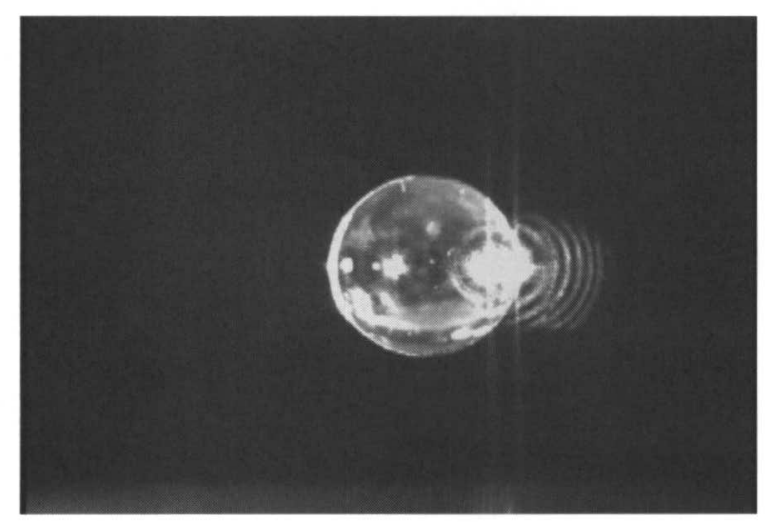

Fig. 15 An electrostatically levitated water drop

実験時の液滴内部の流れを正確に把握しておく必要があ る.

残念ながら, 液体金属は可視光に対して不透明であり, 液滴内部の流れを観察することはできない. そこで, 透 明液体である水を用いたモデル実験を開始している.

Fig. 15 のおおり, 常温での浮遊には既に成功しており, 今後試料にトレーサーを入れて PTV 法などにより液滴 内部の流れの把握を行い, 液滴振動法による表面張力及 び粘性係数に与える流れの影響を評価する予定である.

\section{4. おわりに}

技術的な進展から「浮遊技術」は地上においても一般 に利用可能なものとなってきた. 浮遊技術と可視化観察 技術と組み合わせた研究は今後ますます盛んになってい くものと考えられる.

\section{参考文献}

1 ）山中龍夫, 上村平八郎：音波浮遊装置内での液滴の挙動と音 波干涉履歴の研究, 宇宙開発事業団成果報告 NASDA-TMR940002, Vol. 2 (1994) pp. 724-771.

2) Millot,F., Rifflet, J. C., Sarou-Kanian, V., Wille, G.. : HighTemperature Properties of Liquid Boron from Contactless Techniques, Int. J. of Thermophysics, Vol. 23 (2002) pp. 1185 $-1195$.

3 ) Yasuda, H., Ohnaka, I., Ninomiya, Y., Ishii, R., Fujita, S., Kishio. K. : metallic droplet levitated by simultaneous imposition of the static and the alternating magnetic fields, J. Jpn. Soc. Microgravity Appl., Vol. 20 (2003) pp. 153-159.

4) Rhim, W. K., Chung, S. K., Barber, D., Man, K. F., Gutt, G., Rulison, A., Spjut, R. E.: An electrostatic levitator for hightemperature containerless materials processing in $1-\mathrm{g}, \mathrm{Rev}$. Sci. Instrum., Vol. 64 (1993) pp. 2961-2970.

5 ) Paradis, P. -F., Ishikawa T., Fujii, R., Yoda, S. : Physical Properties of Liquid and Undercooled Tungsten by Levitation Techniques, Appl. Phys. Lett, Vol. 86 (2005) pp. 41901.

6 ) Li, M., Nagashio, K., Ishikawa, T., Yoda, S., Kuribayashi, K. Microtexture and macrotexture formation in the containerless solidification of undercooled $\mathrm{Ni}-18.7$ at $\% \mathrm{Sn}$ eutectic melts, Acta Materialia, Vol. 53 (2005) pp. 731-741.

7 ) Chung, S. K., Thiessen, D.B., Rhim, W. K.: A noncontact measurement technique for the density and thermal expansion coefficient of solid and liquid materials, Rev. Sci. Instrum. Vol. 67 (1996) pp. $3175-3181$.

8 ) Ishikawa, T., Paradis, P.-F., Yoda S. : New sample levitation initiation and imaging techniques for the processing of refractory metals with an electrostatic levitator furnace, Rev. Sci. Instrum. Vol. 72 (2001) pp. 2490-2495.

9 ) Rhim, W. K., Ohsaka, K. Paradis, P.-F. : Noncontact technique for measuring surface tension and viscosity of molten materials using high temperature electrostatic levitation, Rev. Sci. Instrum., Vol. 70 (1999) pp. 2796-2801.

10) Paradis, P.-F., Ishikawa, T., Yoda, S. : Non-contact Measurements of Surface Tension and Viscosity of Niobium, Zirconium and Titanium Using an Electrostatic Levitation Furnace, Int. J. Thermophys., Vol. 23 (2002) pp. 825-842. 

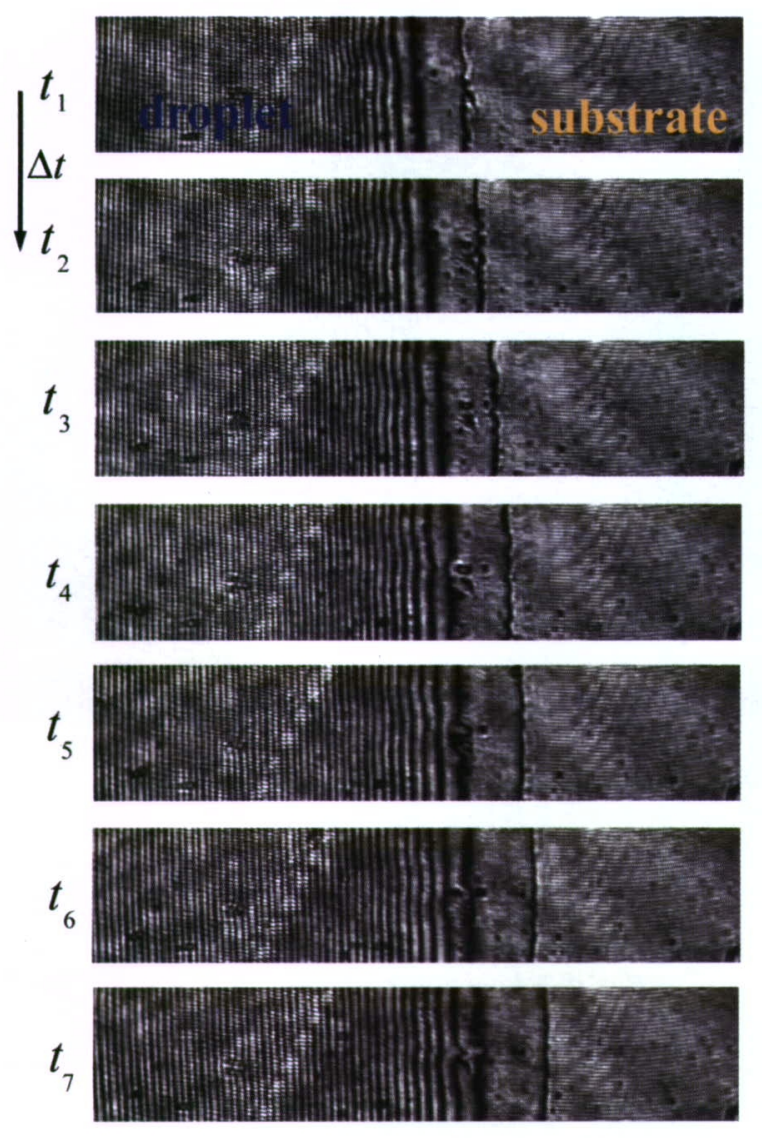

$0.88 \mathrm{~mm}$

$\Delta t=2.0[\mathrm{~s}]$

口絵 4 水平から $15^{\circ}$ 傾斜したカーボン上のシリコーンオイ ル $(10 \mathrm{cST})$ のコンタクトライン. 移動する液滴最 前縁のプロファイルが読み取れる

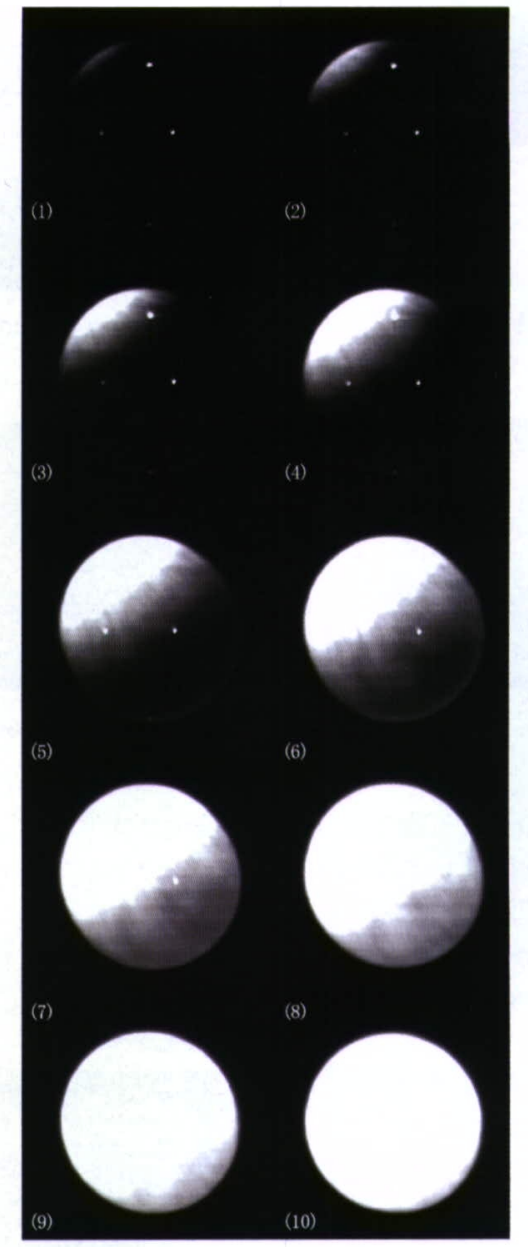

口絵 5 静電浮遊方により浮遊する酸化物試料の過冷却液体 からの凝固過程. 高速度カメラにより $1 \mathrm{msec}$ 毎に 撮影し，凝固速度を求める.

(口絵 4 東北大学 流体科学研究所 小宮 敦樹) (口絵 5 宇宙航空研究開発機構 宇宙科学研究本部 石川 毅彦) (本文 175 頁参照)

(本文 181 頁参照)
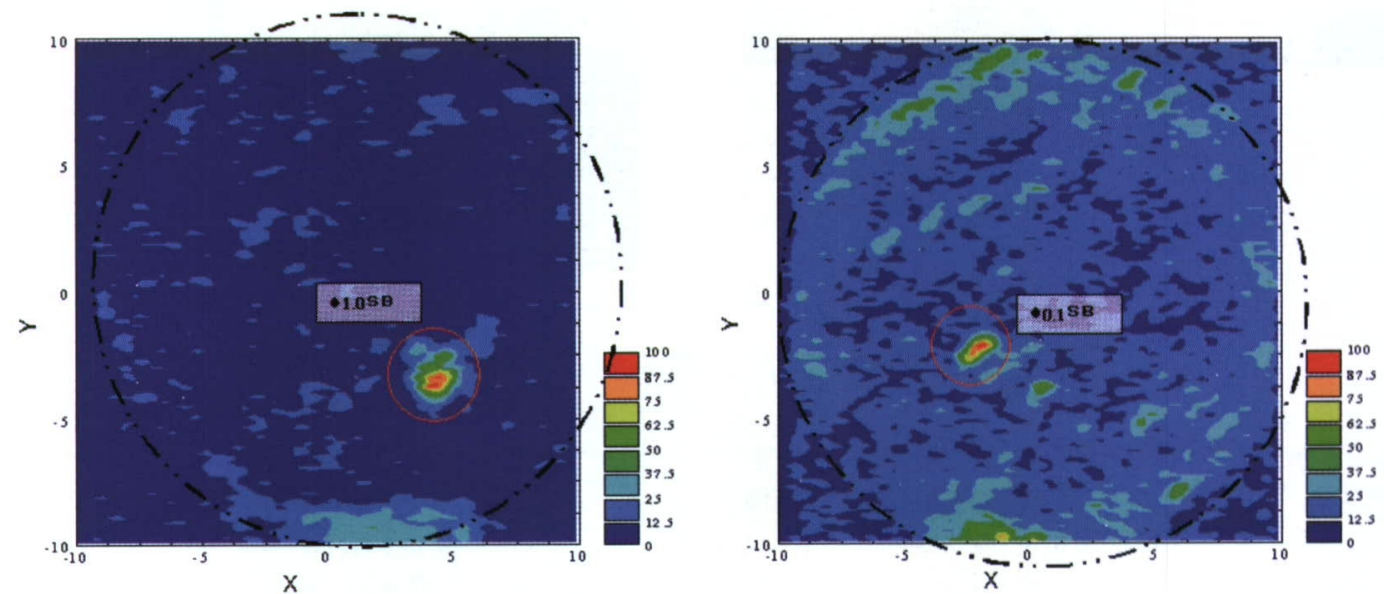

ロ絵 6 開発したトレーサ粒子を固体スズ中に埋め込み超音波スキャンを行ったときの反射エコー強度分布. トレーサ粒子径 $1 \mathrm{~mm}$ (左図), $0.1 \mathrm{~mm}$ (右図)

(口絵 6 宇宙航空研究開発機構 宇宙科学研究本部 松本 聡) (本文 169 頁参照) 


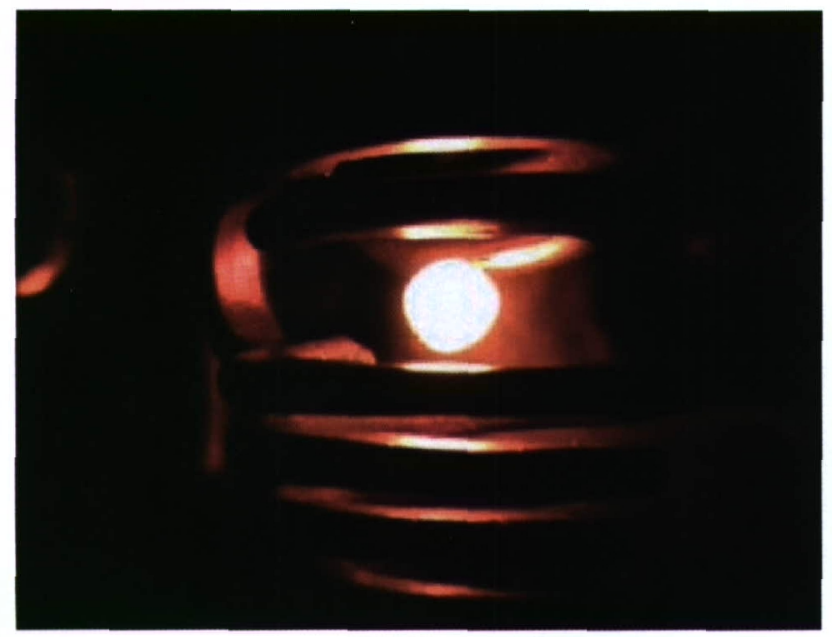

ロ絵7 電磁浮遊法で浮遊するシリコン融液（学習院大学 渡邊教授より提供)

口絵 81986 年, 1GFLOPS $の$ 性能, 256 MB のメモリーを持つ世界最高速の国産 スーパーコンピュータを利用し, 初め て輸送機翼胴結合体のシミュレーショ ンが行われた (右図(a)). 2000 年を超 えた今, エンジンをつけた全機（SST 実験機：横浜国立大学 宮路幸二助教 授, 旧航空宇宙技術研究所 岩宮敏幸) まわりの流れ解析 (下図(b)) が数十分 程度で行える時代になっている.
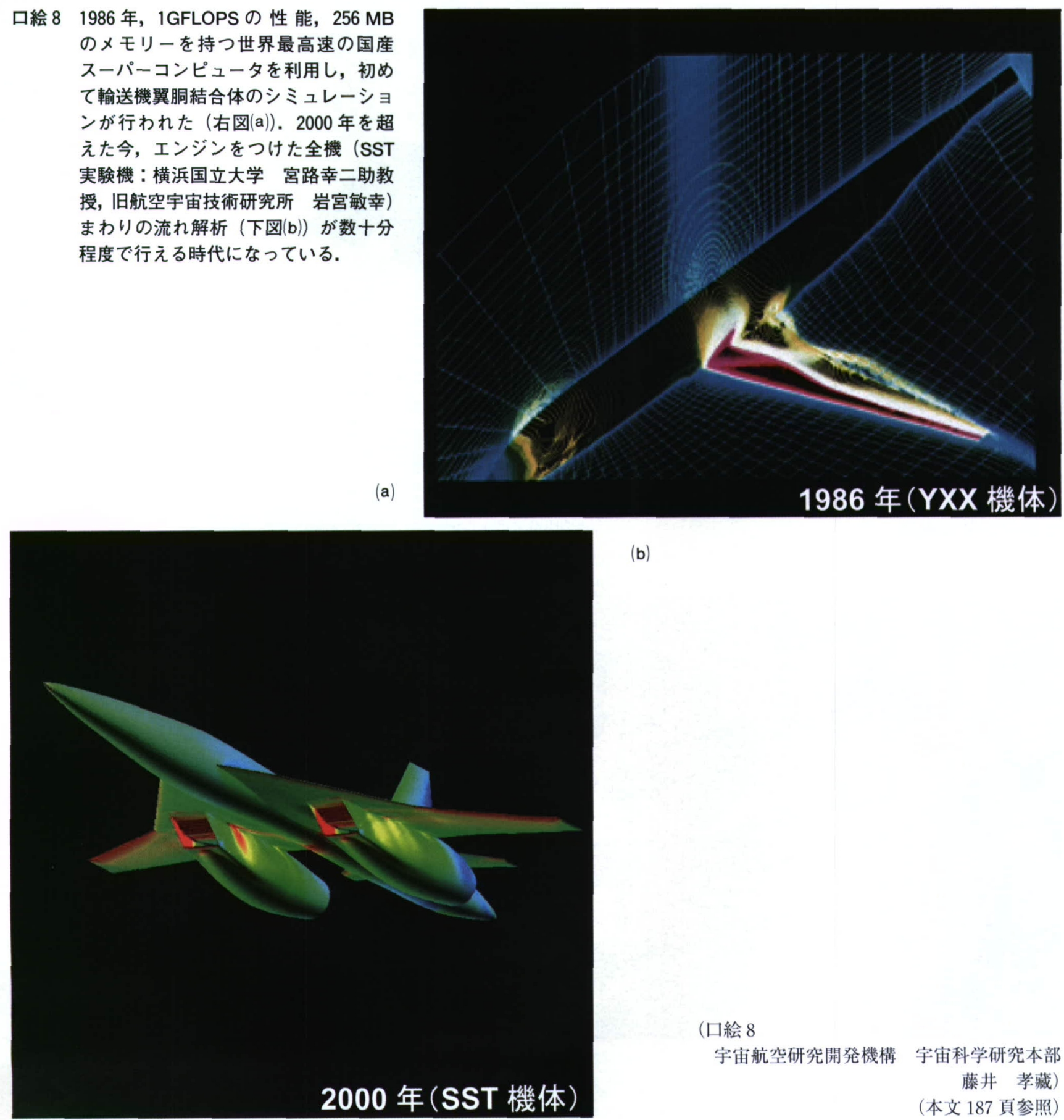

(b)

口絵 7

宇宙航空研究開発機構 宇宙科学研究本部 石川 毅彦) (本文 181 頁参照) 